\title{
Business games in teaching hematology
}

\author{
Kattabek ABDIEV ${ }^{1}$, Lutfulla MAHMONOV², \\ Anajon MADASHEVA ${ }^{3}$, Feruza MAMATKULOVA ${ }^{4}$
}

Samarkand Medical Institute

\begin{tabular}{l} 
ARTICLE INFO \\
\hline Article history: \\
Received October 2021 \\
Received in revised form \\
15 October 2021 \\
Accepted 15 November 2021 \\
Available online \\
25 December 2021 \\
\\
\hline Keywords: \\
business game, \\
active learning method, \\
educational process, \\
formation of teamwork \\
skills, \\
resolving dispute situations, \\
selection of information, \\
development of \\
organizational abilities, \\
independence, \\
creativity.
\end{tabular}

\begin{abstract}
The role and place of gaming technology in the educational process of medical universities depends on the knowledge of teachers to create a combination with other methods of play, other modes of the game. At the same time, it is necessary to understand the theory, education games and functions of technologies.
\end{abstract}

The place of business games in the educational process are determined by the type of discipline. Business games are made before submitting a lecture course to determine knowledge only when its main experience. The teacher carries out business games after lecture materials to strengthen and implement knowledge in the field of knowledge. The third option can form the entire educational process based on a business game based on. In this case, interest is determined by traditional and business games, traditional and business games that integrate future professional activities. The university often uses compact business games designed for practical training. This is the theoretical basis of this study.

2181-1415/C 2021 in Science LLC.

DOI: https://doi.org/10.47689/2181-1415-vol2-iss11/S-pp208-214

This is an open access article under the Attribution 4.0 International (CC BY 4.0) license (https://creativecommons.org/licenses/by/4.0/deed.ru)

\section{Gematologiyani o'qitishda biznes o'yinlari}

\author{
Kalit so'zlar: \\ biznes o'yini, \\ faol o'rganish usuli, \\ konflikt holatlar, \\ axborotni tanlash,
}

\begin{abstract}
ANNOTATSIYA
Tibbiyot oliygohlarining o'quv jarayonida o'yin texnologiyasining roli va o'rni, o'yinning boshqa usullari va o'qitish texnologiyalari bilan uyg'unligini tashkil etish o'qituvchilar bilimlariga bog'liq. Bunda o'yin nazariyasi, ta'lim o'yinlari va texnologiyalarning funksiyalarini tushunish talab etiladi.
\end{abstract}

\footnotetext{
${ }^{1}$ Associate Professor of Hematology Department, Samarkand Medical Institute. Samarkand, Uzbekistan.

2 The head of Hematology Department, Samarkand Medical Institute. Samarkand, Uzbekistan.

${ }^{3}$ Senior teacher of Hematology Department, Samarkand Medical Institute. Samarkand, Uzbekistan.

${ }^{4}$ Assistant of Hematology Department, Samarkand Medical Institute. Samarkand, Uzbekistan.
} 
tashkiliy qobiliyat, mustaqillik, ijodkorlik.
O'quv jarayonidagi biznes o'yinlarining joy vazifalari intizom turi bilan belgilanadi. Biznes o'yinlari faqat o'z asosiy tajribasi bo'lganda, bilimlarni aniqlash uchun ma'ruza kursini taqdim etishdan oldin amalga oshiriladi. O'qituvchi biznes o'yinlarini bilim sohasidagi bilimlarni mustahkamlash va amalga oshirish uchun ma'ruza materiallaridan keyin amalga oshiradi. Uchinchi varianti biznes o'yini asosida olib boriladigan butun o'quv jarayonini tashkil qilishi mumkin. Bunday holda, foizlar kelajakdagi kasbiy faoliyatni yaxlit ravishda tushunadigan an'anaviy va biznes o'yinlari bilan aniqlanadi. Universitet, ko'pincha, amaliy mashg'ulotlar uchun mo'ljallangan ixcham biznes o'yinlaridan foydalanadi. Ushbu tadqiqotning nazariy asosi shulardan iboratdir.

\section{Деловые игры в обучении гематологии}

Ключевые слова:
деловая игра,
метод активного
обучения,
учебный процесс,
формирование навыков
совместной работы,
разрешая ситуации
споров,
подбор информации,
развитие
организационных
способностей,
независимость,
творчество.

\section{АННОТАЦИЯ}

Роль и место игровых технологий в образовательном процессе медицинских университетов, зависит от ознакомленности учителей для создания сочетания с другими методами игры, другими модами игры. В то же время необходимо рассмотреть теорию, образовательные игры и функции технологий.

Место бизнес-игр в образовательном процессе, определяются типом дисциплины. Деловые игры, сделаны до представления курса лекций, чтобы определить знания, только тогда, когда есть, его основной опыт. Преподаватель, проводит деловые игры после лекционных материалов для укрепления и внедрения знаний в области знаний. Третий вариант может сформировать весь учебный процесс на основе бизнес-игры на основе. В этом случае, интерес определяется традиционными и бизнес-играми. Их объединяет, традиционные и деловые игры, которые объединяют будущую профессиональную деятельность. Преподаватели ВУЗов, могут использовать использовать компактные бизнес-игры, предназначенные для практической подготовки. Это теоретическая основа данного исследования.

The task of medical education is to enable students to gain knowledge and personal skills. Interactive methods of conducting classes, leaving the framework of the traditional filing of the material, stimulate interest in its study, involvement in the process of all students, help to receive skills relevant, easy and dynamically, developing initiative, it is easier to understand and memorize material, contribute to the right choice of specialization with students. Therefore, the introduction and use in the learning process, along with active, interactive forms of teaching disciplines, is an important requirement of modern medical education.

"A business game is a method of teaching professional activities through its modeling close to real conditions, with mandatory branching, dynamic development of a solved situation or problem in strict accordance with subsequent events with the nature of decisions and actions adopted by playing in previous stages" [7]. 
One of the forms of interactive classes is a "Business game", which is a joint activity of the participants, in the process of which each of them performs its own task. Knowledge and skills, including practical, who receive during the business game participants, are especially remembered by students. This special experience that allows you to create a relationship model, is important in practical life for the formation of teamwork skills, resolving dispute situations, selection of information, development of organizational abilities, independence, and creative potential.

Business games are an active learning method. They contribute to a more effective learning, acquiring and improving professional skills. The game gives a systematic idea of the content of special knowledge, professional activities with structural and functional components are simulated. A business game makes it possible to get a learning and educational effect, in it the educational process is approaching real conditions. Thus, the purpose of using business games in the training process is the most efficient learning of educational material, the acquisition and improvement of professional knowledge and skills [9].

One of the most promising methods of interactive learning is business games.

The undoubted advantages of this form of study are:

1. Maximum approximately to the real process.

2. The transfer of theoretical knowledge into a practical solution to the tasks supplied by the teacher.

3. The competition of accumulation of professional experience.

4. Ability to "lose" various behaviors strategies and to work out algorithms for solving the tasks.

5. A business game contributes to the accumulation of social experience, including communicative experience.

Business games as an addition to traditional training methods, cognitive activity is intensified, stimulate the development of an individual approach, teach professional orienteering in a particular situation, working in the team and with a team, the ability to accurately and clearly formulate their thoughts, increase the quality of the material learning [2, 3].

Business games are widely used in professional pedagogy; Their classification is shown in Figure 1 [8]. 


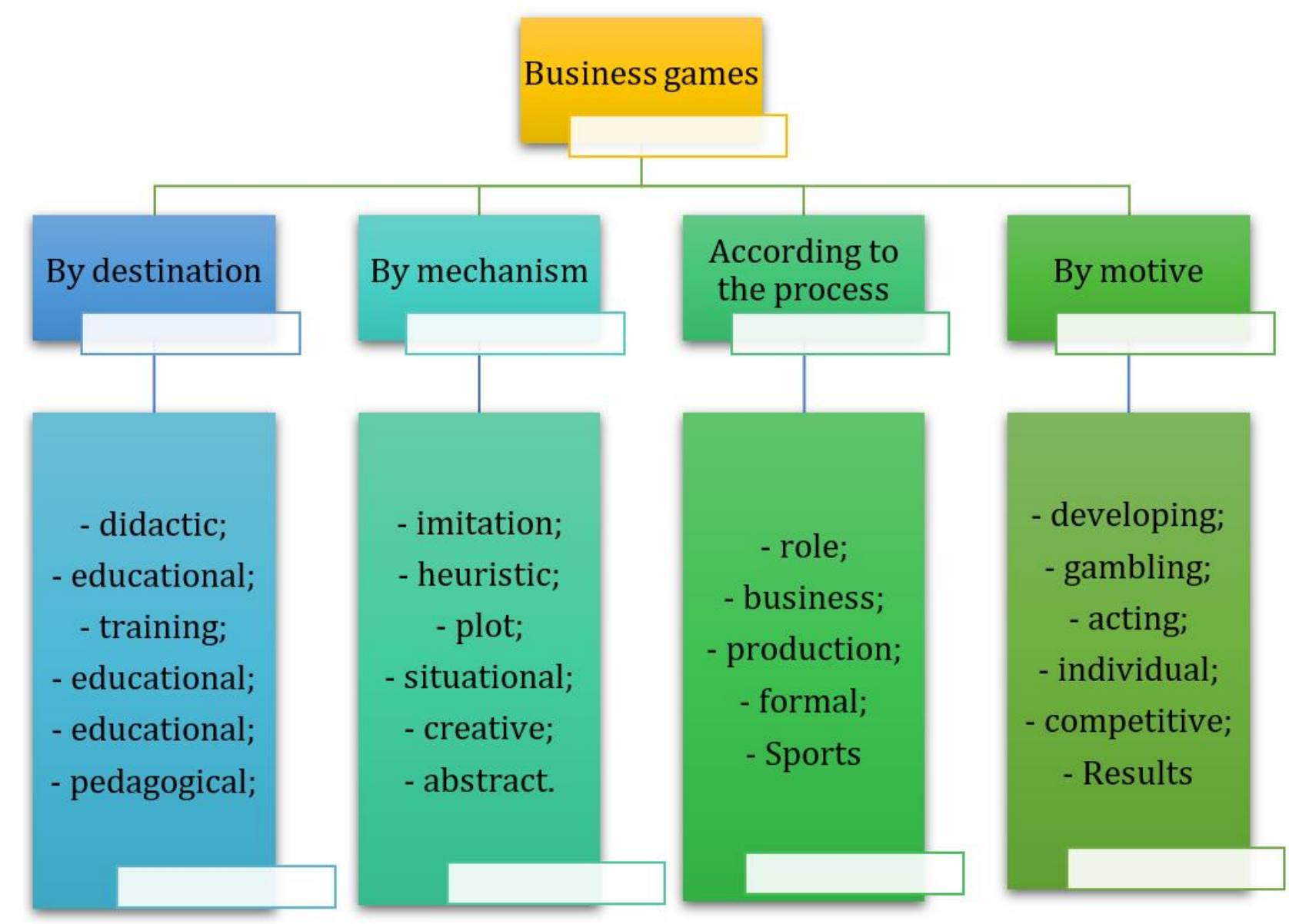

\section{Figure 1 - classification of business games}

A business game in medical education is determined by a complex system of educational and communicative tasks. Its main purpose is the construction and

development of skills and skills to high professional qualifications, reducing the degree of novelty of possible medical and organizational situations in the professional activity of the doctor.

The task of its participants is to develop solutions and models of further behavior.

Business game makes it possible to students:

- Immerse yourself in the atmosphere, extremely close to the doctor's work;

- learn to form an optimal communication model with patients and colleagues;

- Develop the ability to conduct an examination, diagnosis and choose the optimal treatment tactics available to simple methods.

In order for the business game to be successful, you need to correctly calculate the time required to solve the problem, equip the audience, develop a game script based on the curriculum and the subject of classes, to determine its main issues and objectives, and formulate the criteria for evaluating the results.

Before holding a business game, the teacher determines the main questions and goals of a specific game, based on the topic of classes.

When creating a business game, the teacher develops the game script, creates a graphical model of the game, and formulates the basic requirements for an assessment of the game. The basic element of the business game is the script. The script provides for the sequence of the game, the possible roles of the participants of the game. 
In preparation and during the business game, the teacher may face the following problems:

1. Lack of basic experience in conducting games, as well as the lack of recommendation literature to prepare for the game;

2. Methodological difficulties in assessing the effectiveness of different types of business games;

3. Difficulties of playing games, since there is no description of the games in the literature;

4. Difficulties in assessing the results of the game;

5. The emergence of interpersonal conflict during the game;

6. The subsequent intragroup conflict continuing after the game;

7. Manipulating the participants of the game, deviation from the objectives of the educational process.

An important point of business games is preliminary preparation for the game, since it is impossible to play what students do not have ideas, it leads to the profanation of a business game. This means that the participation of students in the game requires the preliminary training and development of relevant competence. The game should be controlled by the teacher, in order to avoid development in the process of excitability and uncontrolled emotions on the part of students. The teacher is most active at the development stage, preparation of the game, as well as in the final period, during the conclusions of the game. Students require compliance with the rules of the game and the disciplines that must be voiced before each game.

In the training of nursing staff, you can allocate the following objectives of the business games:

1. Immersion of students in the atmosphere extremely close to the professional work of the doctor,

2. Formation of clinical thinking among students,

3. Development of the ability to conduct differential diagnosis and appoint optimal survey tactics and treatment with simple and accessible methods,

4. Formation of an optimal model of communication with patients and colleagues at work,

5. Control of professional training of students through business games, orienting students in subsequent practical life,

6. Educational function of games.

Business Games in medical education fulfill an educational role, the main meaning of them is the training of specialists, their training and development of professional skills and skills to high qualifications.

In medical training, you can allocate the following models of games:

1. The educational game "Doctor and Patient" - this form is variable, can be used in various forms, for example, from the only player with a student teacher before applying this game at the lecture when the lecturer leads the game with a large number of students.

2. The educational game "Concilium" - the game is distinguished by the fact that in addition to the attending physician, consultants and experts participate in the game. Formally, this type of occupation is a role-playing game, which provides in the group the role of physicians of various specialties, forming communicative skills and collaboration skills. 
3. The training game "Nursing post" - allows students to explore the work and organization of the nursing post, the function and relationship between the nursing staff, medical personnel and patients.

Business games used in the educational process have broad didactic capabilities as they provide:

- consolidation and integrated application of knowledge obtained by students (listeners) when studying different disciplines (integration role of games), the formation of a clear idea of professional activities in a selected specialty;

- development of educational skills of effective management of real processes, including with the help of modern mathematical methods and technical means;

- Mastering the features of collective professional activities, acquiring the skills of organizing interaction with the provision and service bodies.

Gaming technologies refer to the category of private training technologies that allow several pedagogical tasks at once.

How to differentiate - Does the teacher use a game method or uses game technology? When, in the process of studying a specific discipline, the educational game was rarely used or once, then we can talk about the use of the game method. If throughout the time allocated to the study of this discipline, the teacher solves the didactic tasks using a variety of games and the corresponding methodological support, we can talk about the use of gaming technology.

By using these games, the teacher can develop and create his own games for students, while it is important to take into account the goals of the game and the focus of the game (educational or organizational). The most complex games can be the educational games "Polyclinic", "Hospital”, etc.

The main purpose of the business games in medical education is a decrease in the degree of novelty and the surprises of the probable medical and organizational situations in the professional sphere of the doctor.

To sum up, the modern system of secondary vocational education is experiencing reforming providing for the transition to level preparation. A modern form of training treats competences as an ability to apply knowledge, skills and personal qualities for successful activities in a particular area. According to modern requirements, "the implementation of the competence approach should provide for widespread use in the educational process of active and interactive forms of classes." The proportion of such classes in the educational process should be $20-30 \%$ of audit classes, depending on the direction of preparation.

The most often used by teachers a traditional method of teaching medical disciplines (lecture supply of material), but the interest of students to gaming training methods requires the teacher to study new methods of filing material, therefore the use of interactive learning methods in medical education is a promising direction for the further development of teaching experience and skill.

The educational process based on the use of interactive learning methods is organized, taking into account the inclusion in the process of knowing all students of the group without exception. Joint activity means that everyone makes a special individual contribution, in the course of work there is an exchange of knowledge, ideas, ways of activity. Interactive methods are based on the principles of interaction, the activity of trainees, support for group experience, mandatory feedback. 
Business games, master classes, situational analysis, round table, trainings, as well as other forms of interactive classes contribute to improving interest among students to studied material, and also contribute to the development of professional skills and communicative abilities in students.

\section{REFERENCES:}

1. Аверин В.А. Психология медицинского образования / В.А.Аверин, Т.Л. Бухарин - Санкт-Петербург, 1994. - С. 167.

2. Воробьев А.И. Кафедра гематологии Российской медицинской академии последипломного образования / А.И. Воробьев, С.К. Кравченко, Н.Е. ШкловскийКорди // Российские медицинские вести. - 2001. - № 1. - С. 12.

3. Дещёкина М.Ф., Дианкина М.С., Ильенко Л.И., Леничеко В.П. Деловая клиническая игра в медицинском институте // Педиатрия им. Сперанского. 1989. № 3. - С. 69-72.

4. Дианкина М.С. «Профессионализм преподавателя высшей медицинской школы (психолого-педагогический аспект). Москва, 2000.

5. Кичевский Р.Л. Психология лидерства / Р.Л. Кичевский - М.: Статут, 2007. C. 542.

6. Лернер И.Я. Дидактические основы методов обучения / И.Я. Лернер. - М.: Педагогика, 1981. - С. 186.

7. Наумов Л.Б. Учебные игры в медицине - Ташкент, 1986. - С. 62.

8. Сафин Р.С. Дидактические основы проектирования экономических технологий обучения / Р.С. Сафин. - Казань: изд-во КГУ, 2004. - С. 556.

9. Состояние и перспективы последипломного образования. Тезисы межвузовской учебно- методической конференции. - Казань, 1996. - С. 216. 